\title{
Amomum villosum Leaf Oil
}

National Cancer Institute

\section{Source}

National Cancer Institute. Amomum villosum Leaf Oil. NCI Thesaurus. Code C107261.

The essential oil of Amomum villosum. Black cardamom oil is used for treatment of the digestive tract. 